\title{
Three New Nortriterpene Glycosides and Two New Triterpene Glycosides from the Bulbs of Scilla scilloides
}

\author{
Masateru Ono, ${ }^{*, a}$ Daiki Toyohisa, ${ }^{a}$ Takahiro Morishita, ${ }^{a}$ Hiroki Horita, ${ }^{a}$ Shin Yasuda,${ }^{a}$ \\ Yoichiro NishidA, ${ }^{b}$ Toshiharu TanaKa,${ }^{b}$ Masafumi OKaWA, ${ }^{c}$ Junei KInJO, ${ }^{c}$ \\ Hitoshi Yoshimitsu, ${ }^{d}$ and Toshihiro NOHARA ${ }^{d}$ \\ ${ }^{a}$ School of Agriculture, Tokai University; 5435 Minamiaso, Aso, Kumamoto 869-1404, Japan: ${ }^{b}$ Aso Pharmaceutical Co. \\ Ltd.; 91-1 Tsukure, Kikuyo, Kumamoto 869-1101, Japan: ' ${ }^{c}$ Faculty of Pharmaceutical Sciences, Fukuoka University; \\ 8-19-1 Nanakuma, Jonan-ku, Fukuoka 814-0180, Japan: and ${ }^{d}$ Faculty of Pharmaceutical Sciences, Sojo University; \\ 4-22-2 Ikeda, Kumamoto 860-0082, Japan
}

Received June 17, 2011; accepted August 18, 2011; published online August 23, 2011

Three new norlanostane-type triterpene glycosides, scillanostasides A, B, and C, and two new lanostane-type triterpene glycosides, scillanostasides D and E, were isolated from the bulbs of Scilla scilloides Druce (Liliaceae) along with one known norlanostane-type triterpene heptaglycoside, scillascilloside G-1. Their chemical structures were determined on the basis of spectroscopic data as well as chemical evidence.

Key words Scilla scilloides; triterpene; lanostane; glycoside; scillanostaside; Liliaceae

Scilla scilloides DRUCE is a perennial herb belonging to the Liliaceae family. The bulb of this plant has been used as a foodstuff, a traditional medicine for promoting blood circulation, an anti-inflammatory agent, and an analgesic. ${ }^{1)}$ With regard to the chemical constituents of this bulb, the presence of homoisoflavones, norlanostane-type triterpenes, and lanostane-type triterpenes has been reported. ${ }^{2-6)}$ In a previous paper, ${ }^{7}$ we reported the isolation and structural elucidation of a new homostilbene and two new homoisoflavones from the methanol $(\mathrm{MeOH})$ extract of fresh bulbs of $S$. scilloides along with 13 known compounds consisting of a homostilbene, seven homoisoflavones, a xanthone, a lignan, and three norlanostane-type triterpenes. As part of an ongoing study of this plant, we describe the isolation and structural characterization of three new norlanostane-type triterpene glycosides and two new lanostane-type triterpene glycosides along with one known norlanostane-type triterpene glycoside from the $\mathrm{MeOH}$ extract.
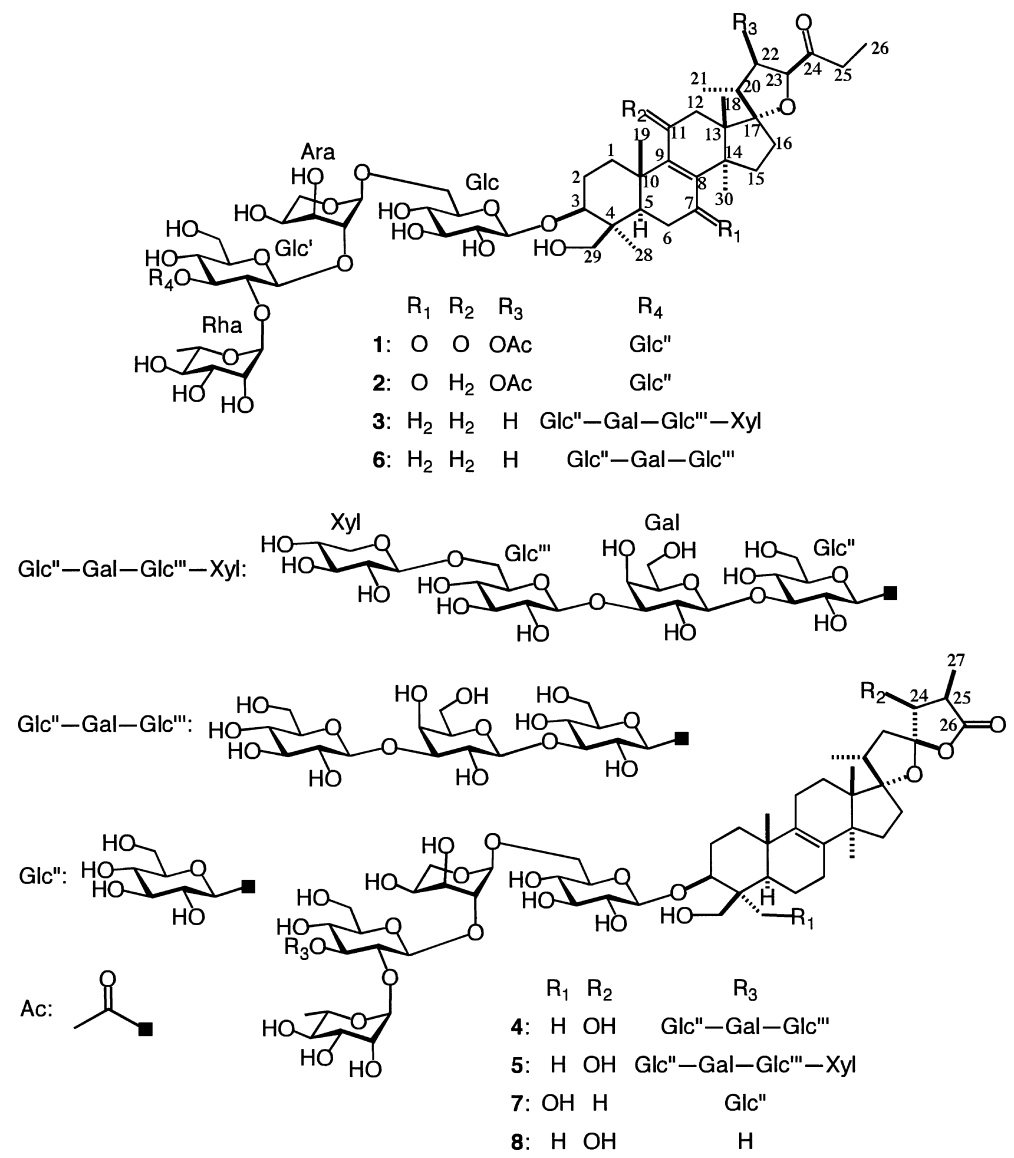

Fig. 1. Structures of $\mathbf{1}-\mathbf{8}$ 
Table 1. ${ }^{1} \mathrm{H}-\mathrm{NMR}$ Spectral Data for Aglycone Moiety of $\mathbf{1}$ and $\mathbf{2}$ (in Pyridine- $d_{5}, 500 \mathrm{MHz}$ )

\begin{tabular}{|c|c|c|}
\hline & 1 & 2 \\
\hline Ag-1a & 3.13 ddd $(4.0,4.0,13.5)$ & 1.83 ddd $(4.0,4.0,13.5)$ \\
\hline $1 b$ & $1.37 \mathrm{~m}$ & 1.39 ddd $(4.0,13.5,13.5)$ \\
\hline $2 \mathrm{a}$ & $2.34 \mathrm{~m}$ & $2.37 \mathrm{~m}$ \\
\hline $2 b$ & $2.20 \mathrm{~m}$ & 2.09 \\
\hline 3 & 3.63 & 3.62 \\
\hline 5 & $1.87 \mathrm{dd}(4.0,13.0)$ & $1.92 \mathrm{dd}(7.0,9.5)$ \\
\hline $6 a$ & 2.90 & 2.81 \\
\hline $6 b$ & 2.86 & 2.77 \\
\hline $11 \mathrm{a}$ & & 2.50 \\
\hline $11 b$ & & $2.29 \mathrm{~m}$ \\
\hline $12 \mathrm{a}$ & $3.45 \mathrm{~d}(16.0)$ & 2.47 \\
\hline $12 b$ & $2.63 \mathrm{~d}(16.0)$ & $1.58 \mathrm{~m}$ \\
\hline $15 \mathrm{a}$ & 2.67 & 2.67 \\
\hline $15 b$ & $2.08 \mathrm{~m}$ & 2.06 \\
\hline $16 \mathrm{a}$ & 2.69 & 2.72 \\
\hline $16 b$ & 1.97 & 2.11 \\
\hline 18 & $1.01 \mathrm{~s}$ & $0.89 \mathrm{~s}$ \\
\hline 19 & $1.49 \mathrm{~s}$ & $1.15 \mathrm{~s}$ \\
\hline 20 & $2.38 \mathrm{q}$ like $(6.0)$ & $2.41 \mathrm{q}$ like (6.5) \\
\hline 21 & $1.02 \mathrm{~d}(6.0)$ & $1.11 \mathrm{~d}(6.5)$ \\
\hline 22 & $5.40 \mathrm{~d}(5.5)$ & $5.41 \mathrm{~d}(5.0)$ \\
\hline 23 & $4.99 \mathrm{~d}(5.5)$ & $5.00 \mathrm{~d}(5.0)$ \\
\hline 25 & $2.52 \mathrm{q}(7.0)$ & $2.58 \mathrm{q}(7.0)$ \\
\hline 26 & $1.08 \mathrm{t}(7.0)$ & $1.08 \mathrm{t}(7.0)$ \\
\hline 28 & $1.52 \mathrm{~s}$ & $1.50 \mathrm{~s}$ \\
\hline $29 a$ & $4.43 \mathrm{~d}(11.0)$ & $4.42 \mathrm{~d}(11.5)$ \\
\hline $29 b$ & $3.87 \mathrm{~d}(11.0)$ & $3.83 \mathrm{~d}(11.5)$ \\
\hline 30 & $1.93 \mathrm{~s}$ & $1.74 \mathrm{~s}$ \\
\hline $\mathrm{COCH}_{3}$ & $1.97 \mathrm{~s}$ & $1.95 \mathrm{~s}$ \\
\hline
\end{tabular}

$\delta$ in ppm from tetramethylsilane (TMS) (coupling constants $(J$ in $\mathrm{Hz})$ are given in parentheses).

The $\mathrm{MeOH}$ extract of the fresh bulbs of S. scilloides was suspended in $\mathrm{H}_{2} \mathrm{O}$ and successively extracted with ethyl acetate $(\mathrm{EtOAc})$ and $n$-butanol $(\mathrm{BuOH})$. Repeated chromatography of the aqueous layer with Diaion HP20, silica gel, and Chromatorex octadecyl silica (ODS) column chromatography as well as HPLC on ODS and silica gel led to the isolation of six compounds $(\mathbf{1}-\mathbf{6})$.

Compound 6 was identified as scillascilloside G-1 on the basis of its physical and spectral data (Fig. 1). ${ }^{5}$

Compound $\mathbf{1}$, tentatively named scillanostaside A, was obtained as an amorphous powder. In negative-ion FAB-MS, 1 gave an $[\mathrm{M}-\mathrm{H}]^{-}$ion peak at $\mathrm{m} / \mathrm{z} 1307$ along with fragment ion peaks at $m / z$ 1247 [1307-60 $\left(\mathrm{C}_{2} \mathrm{H}_{4} \mathrm{O}_{2}\right.$, acetic acid unit) $]^{-}, 1101$ [1247-146 $\left(\mathrm{C}_{6} \mathrm{H}_{10} \mathrm{O}_{4}\right.$, methyl pentosyl unit $\left.)\right]^{-}$, $1085\left[1247-162\left(\mathrm{C}_{6} \mathrm{H}_{10} \mathrm{O}_{5} \text {, hexosyl unit }\right)\right]^{-}, 939[1085-$ $146]^{-}$, and 777 [939-162] $]^{-}$. High-resolution (HR)-positiveion FAB-MS showed the molecular formula of $\mathbf{1}$ to be $\mathrm{C}_{60} \mathrm{H}_{92} \mathrm{O}_{31}$. The ${ }^{1} \mathrm{H}-\mathrm{NMR}$ spectrum of $\mathbf{1}$ indicated signals due to four tertiary methyl groups $(\delta 1.93,1.52,1.49,1.01)$, two secondary methyl groups $[\delta 1.72(\mathrm{~d}, J=6.5 \mathrm{~Hz}), 1.02(\mathrm{~d}, J=$ $6.0 \mathrm{~Hz})]$, one primary methyl group $[\delta 1.08(\mathrm{t}, J=7.0 \mathrm{~Hz})]$, one acetyl group $(\delta 1.97)$, and five anomeric protons $[\delta 6.29$ (br s), 5.28 (d, $J=2.0 \mathrm{~Hz}), 5.16$ (d, $J=7.5 \mathrm{~Hz}), 5.02$ (d, $J=$ $7.5 \mathrm{~Hz}), 4.89(\mathrm{~d}, J=7.5 \mathrm{~Hz})]$. The ${ }^{13} \mathrm{C}-\mathrm{NMR}$ spectrum of $\mathbf{1}$ exhibited signals due to three keto carbonyl carbons ( $\delta$ $208.0,202.4,202.0)$, one ester carbonyl carbon ( $\delta$ 169.8), two olefinic carbons $(\delta 151.8,151.1)$, and five anomeric carbons $(\delta 106.2,104.2,102.5,102.0,101.1)$. The ${ }^{1} \mathrm{H}-$ and ${ }^{13} \mathrm{C}$ NMR spectra were similar to those of $\mathbf{6}$, apart from the ap-
Table 2. ${ }^{1}$ H-NMR Spectral Data for Sugar Moiety of $\mathbf{1}$ and 2 (in Pyridine$d_{5}, 500 \mathrm{MHz}$

\begin{tabular}{|c|c|c|}
\hline & 1 & 2 \\
\hline Glc-1 & $4.89 \mathrm{~d}(7.5)$ & $4.92 \mathrm{~d}(8.0)$ \\
\hline 2 & 3.95 & $3.96 \mathrm{dd}(8.0,8.5)$ \\
\hline 3 & 4.13 & 4.13 \\
\hline 4 & 4.14 & 4.14 \\
\hline 5 & 3.98 & 4.00 \\
\hline $6 a$ & 4.50 & $4.57 \mathrm{dd}(3.0,11.0)$ \\
\hline $6 b$ & 4.20 & 4.24 \\
\hline Ara-1 & $5.28 \mathrm{~d}(2.0)$ & $5.33 \mathrm{~d}(2.5)$ \\
\hline 2 & 4.64 & $4.69 \mathrm{dd}(2.5,5.5)$ \\
\hline 3 & 4.64 & $4.66 \mathrm{dd}(3.0,5.5)$ \\
\hline 4 & 4.51 & 4.54 \\
\hline $5 \mathrm{a}$ & $4.33 \mathrm{dd}(8.0,11.0)$ & $4.36 \mathrm{dd}(8.0,11.5)$ \\
\hline $5 b$ & 3.87 & $3.91 \mathrm{dd}(3.5,11.5)$ \\
\hline Glc'-1 & $5.16 \mathrm{~d}(7.5)$ & $5.20 \mathrm{~d}(8.0)$ \\
\hline 2 & 4.18 & 4.19 \\
\hline 3 & 4.06 & 4.06 \\
\hline 4 & 4.06 & 4.07 \\
\hline 5 & 3.63 & 3.62 \\
\hline $6 \mathrm{a}$ & 4.21 & 4.22 \\
\hline $6 b$ & 4.16 & 4.14 \\
\hline Rha-1 & 6.29 br s & $6.32 \mathrm{~d}(1.5)$ \\
\hline 2 & $4.81 \mathrm{brs}$ & $4.81 \mathrm{dd}(1.5,3.0)$ \\
\hline 3 & $4.60 \mathrm{dd}(3.0,9.5)$ & $4.61 \mathrm{dd}(3.0,9.5)$ \\
\hline 4 & 4.25 & $4.27 \mathrm{dd}(9.5,9.5)$ \\
\hline 5 & $4.84 \mathrm{dq}(9.0,6.5)$ & $4.88 \mathrm{dq}(9.5,6.5)$ \\
\hline 6 & $1.72 \mathrm{~d}(6.5)$ & $1.76 \mathrm{~d}(6.5)$ \\
\hline Glc"-1 & $5.02 \mathrm{~d}(7.5)$ & $5.01 \mathrm{~d}(7.5)$ \\
\hline 2 & 3.96 & 3.98 \\
\hline 3 & 4.18 & $4.24 \mathrm{dd}(9.0,9.0)$ \\
\hline 4 & 4.06 & $4.07 \mathrm{dd}(9.0,9.0)$ \\
\hline 5 & 3.96 & 3.97 \\
\hline $6 a$ & 4.51 & $4.52 \mathrm{dd}(2.0,11.5)$ \\
\hline $6 b$ & 4.23 & 4.23 \\
\hline
\end{tabular}

$\delta$ in ppm from TMS (coupling constants ( $J$ in Hz) are given in parentheses)

pearance of signals due to two carbonyl groups, one acetoxy group, and one oxygenated methine group and the loss of signals due to three methylene groups and two monosaccharide units. The NMR signals were assigned in detail with the aid of ${ }^{1} \mathrm{H}-{ }^{1} \mathrm{H}$ correlation spectroscopy (COSY), heteronuclear multiple-quantum coherence (HMQC), heteronuclear multiple-bond correlation (HMBC), and total correlation spectroscopy (TOCSY) techniques (Tables 1-4). In the HMBC spectrum of $\mathbf{1}$, the keto carbonyl carbon at $\delta 202.0$ showed long-range correlations with the methylene protons assignable to $\mathrm{H}_{2}-6$ of aglycone moiety (Agl) at $\delta 2.90$ and 2.86, with which the methine proton due to $\mathrm{H}-5$ of Agl at $\delta$ 1.87 exhibited correlations in the ${ }^{1} \mathrm{H}-{ }^{1} \mathrm{H}$ COSY spectrum. Further, cross-peaks between the keto carbonyl carbon at $\delta$ 202.4 and the methylene protons due to $\mathrm{H}_{2}-12$ of $\mathrm{Agl}$ at $\delta$ 3.45 and 2.63 were observed in the HMBC spectrum. In addition, the ester carbonyl carbon at $\delta 169.8$ exhibited a longrange correlation with the oxygenated methine proton at $\delta$ 5.40 assignable to $\mathrm{H}-22$ of Agl. The foregoing correlations indicated the presence of two carbonyl groups at C-7 and C11 and an acetoxy group at C-22 of Agl. Thus, the planar structure of 1 was a pentaglycoside of 22-acetoxy-17,23epoxy-3,28-dihydroxy-27-nor-lanost-8-ene-7,11,24-trione, as illustrated in Fig. 2. On acidic hydrolysis, 1 afforded L-rhamnose, L-arabinose, and D-glucose, which were identified by optical rotation using chiral detection in HPLC analysis, together with several unidentified artificial aglycones. The cou- 


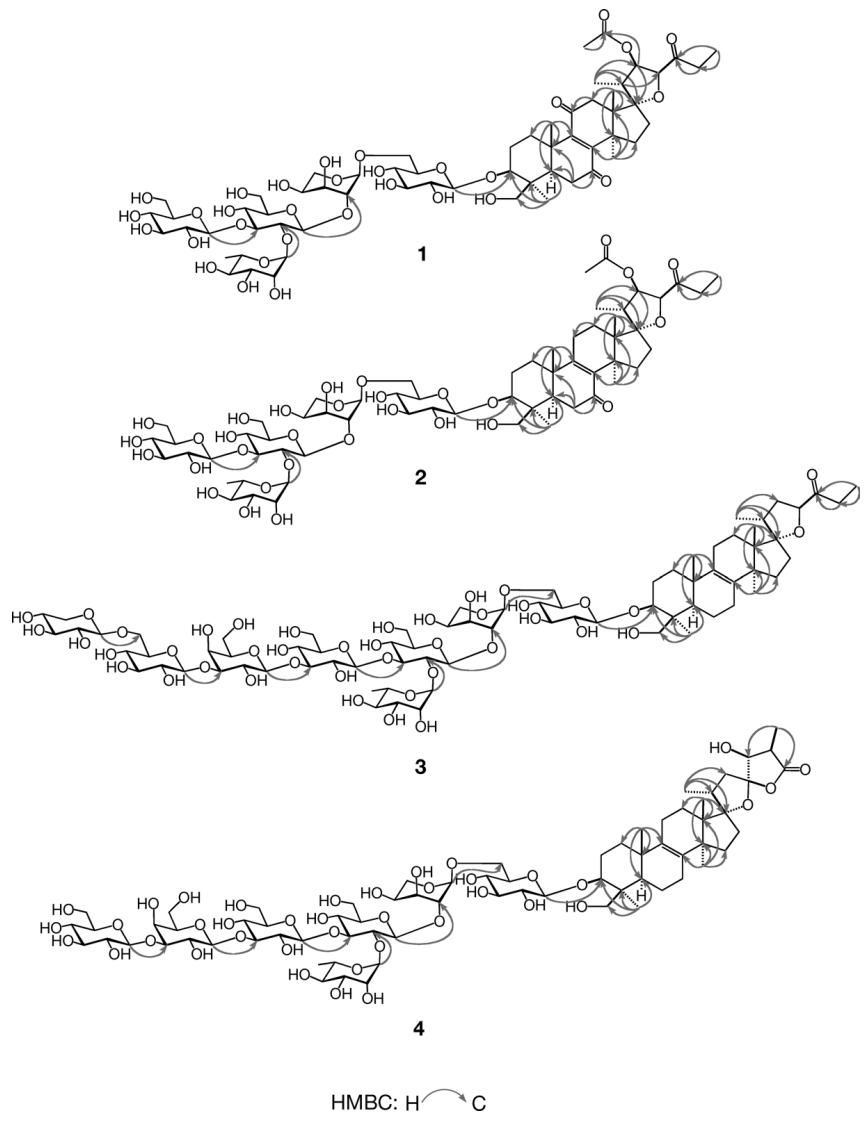

Fig. 2. ${ }^{1} \mathrm{H}-{ }^{13} \mathrm{C}$ Long-Range Correlations Observed in the HMBC Spectra of $1-4$ (in Pyridine- $d_{5}, 500 \mathrm{MHz}$ )

pling constants of the signals due to the anomeric protons in the ${ }^{1} \mathrm{H}-\mathrm{NMR}$ spectrum and the chemical shifts ${ }^{8,9)}$ of the signals due to arabinosyl and rhamnosyl units in the ${ }^{13} \mathrm{C}-\mathrm{NMR}$ spectrum suggested that all monosaccharide units were of the pyranose form. Furthermore, the mode of glycosidic linkages of glucopyranosyl units were $\beta$ in ${ }^{4} \mathrm{C}_{1}$ conformation and those of arabinopyranosyl and rhamnopyranosyl units were $\alpha$ in ${ }^{1} \mathrm{C}_{4}$ conformation. The HMBC spectrum of $\mathbf{1}$ showed key correlations between $\mathrm{H}-1$ of the first glucosyl unit (Glc) and $\mathrm{C}-3$ of Agl; $\mathrm{H}-1$ of the second glucosyl unit $\left(\mathrm{Glc}^{\prime}\right)$ and $\mathrm{C}-2$ of the arabinosyl unit (Ara); H-1 of the rhamnosyl unit (Rha) and $\mathrm{C}-2$ of Glc'; and $\mathrm{H}-1$ of the third glucosyl unit $\left(\mathrm{Glc}^{\prime \prime}\right)$ and $\mathrm{C}-3$ of $\mathrm{Glc}^{\prime}$ (Fig. 2). In addition, the ${ }^{13} \mathrm{C}-\mathrm{NMR}$ spectral data of the sugar moiety of $\mathbf{1}$ were considerably similar to those of scillasaponin B (7) (Fig. 1) ${ }^{10)}$ These data indicated that the sugar chain attached to the hydroxyl group at C-3 of $\mathrm{Agl}$ of 1 was identical to that of 7. The stereochemistry of $\mathrm{Agl}$ was defined on the basis of the nuclear Overhauser effect spectroscopy (NOESY) and the ${ }^{13} \mathrm{C}-\mathrm{NMR}$ spectra of $\mathbf{1}$. In the NOESY spectrum, key nuclear Overhauser effect (NOE) correlations were observed between $\mathrm{H}-3$ and $\mathrm{H}_{3}-28 ; \mathrm{H}-5$ and $\mathrm{H}_{3}$ 28; $\mathrm{Hb}-12$ and $\mathrm{H}_{3}-21$; $\mathrm{Ha}-12$ and $\mathrm{H}_{3}-30 ; \mathrm{H}_{3}-18$ and $\mathrm{H}_{3}-19$; $\mathrm{H}_{3}-18$ and $\mathrm{H}-20 ; \mathrm{H}_{3}-19$ and $\mathrm{H}_{2}-29 ; \mathrm{H}_{3}-21$ and $\mathrm{H}-22$; and $\mathrm{H}_{3}-$ 21 and H-23 (Fig. 3). Moreover, the resonances due to C$20-\mathrm{C}-26$ in the ${ }^{13} \mathrm{C}$-NMR spectrum were superimposable on those of $(22 R, 23 S)$-22-acetoxy-17 $\alpha, 23$-epoxy-3 $\beta, 29$-dihydroxy-27-nor-lanost-8-ene-24-one. ${ }^{11)}$ The structure of 1 was thus concluded to be $(22 R, 23 S)$-22-acetoxy-17 $\alpha, 23$-epoxy$3 \beta, 29$-dihydroxy-27-nor-lanost-8-ene-7,11,24-trione $3-O-\alpha$ -
Table 3. ${ }^{13} \mathrm{C}-\mathrm{NMR}$ Spectral Data for Aglycone Moiety of $\mathbf{1}-\mathbf{6}$ (in Pyridine- $d_{5}, 125 \mathrm{MHz}$ )

\begin{tabular}{|c|c|c|c|c|c|c|}
\hline & 1 & 2 & 3 & 4 & 5 & 6 \\
\hline 1 & 34.4 & 35.0 & 35.7 & 35.7 & 35.7 & 35.7 \\
\hline 2 & 27.2 & 27.1 & 27.4 & 27.4 & 27.4 & 27.4 \\
\hline 3 & 87.4 & 87.8 & 88.9 & 88.9 & 89.0 & 88.9 \\
\hline 4 & 44.0 & 44.1 & 44.3 & 44.4 & 44.3 & 44.4 \\
\hline 5 & 51.0 & 50.9 & 51.7 & 51.7 & 51.7 & 51.8 \\
\hline 6 & 37.4 & 37.5 & 18.7 & 18.7 & 18.6 & 18.7 \\
\hline 7 & 202.0 & 198.3 & 26.8 & 26.8 & 26.8 & 26.9 \\
\hline 8 & 151.1 & 139.5 & 135.2 & 135.0 & 135.0 & 135.4 \\
\hline 9 & 151.8 & 164.5 & 134.5 & 134.7 & 134.7 & 134.6 \\
\hline 10 & 39.8 & 39.6 & 36.7 & 36.8 & 36.8 & 36.8 \\
\hline 11 & 202.4 & 23.6 & 21.0 & 20.9 & 20.9 & 21.1 \\
\hline 12 & 47.5 & 24.7 & 25.2 & 24.9 & 24.9 & 25.3 \\
\hline 13 & 50.2 & 48.8 & 48.8 & 48.7 & 48.7 & 48.9 \\
\hline 14 & 51.9 & 50.4 & 50.8 & 50.7 & 50.7 & 50.8 \\
\hline 15 & 34.1 & 34.2 & 32.0 & 31.8 & 31.8 & 32.1 \\
\hline 16 & 38.6 & 39.6 & 39.6 & 37.7 & 37.7 & 39.7 \\
\hline 17 & 96.0 & 96.2 & 97.0 & 99.2 & 99.1 & 97.1 \\
\hline 18 & 20.0 & 19.4 & 19.2 & 18.7 & 18.6 & 19.3 \\
\hline 19 & 17.5 & 18.3 & 19.5 & 19.5 & 19.5 & 19.5 \\
\hline 20 & 49.3 & 49.5 & 43.6 & 43.8 & 43.8 & 43.7 \\
\hline 21 & 14.8 & 15.4 & 17.2 & 18.6 & 18.6 & 17.2 \\
\hline 22 & 81.5 & 82.0 & 36.8 & 38.4 & 38.4 & 36.9 \\
\hline 23 & 85.0 & 85.0 & 81.5 & 117.0 & 116.9 & 81.6 \\
\hline 24 & 208.0 & 208.9 & 212.6 & 77.4 & 77.4 & 212.5 \\
\hline 25 & 33.2 & 33.4 & 32.2 & 41.2 & 41.2 & 32.3 \\
\hline 26 & 7.5 & 7.5 & 7.7 & 178.7 & 178.7 & 7.7 \\
\hline 27 & & & & 8.8 & 8.8 & \\
\hline 28 & 22.9 & 22.5 & 23.0 & 23.1 & 23.0 & 23.1 \\
\hline 29 & 63.1 & 62.9 & 63.1 & 63.1 & 63.1 & 63.1 \\
\hline 30 & 28.6 & 27.5 & 26.3 & 25.9 & 25.9 & 26.4 \\
\hline $\mathrm{CO}$ & 169.8 & 169.9 & & & & \\
\hline $\mathrm{CH}_{3}$ & 20.7 & 20.8 & & & & \\
\hline
\end{tabular}

$\delta$ in ppm from TMS.

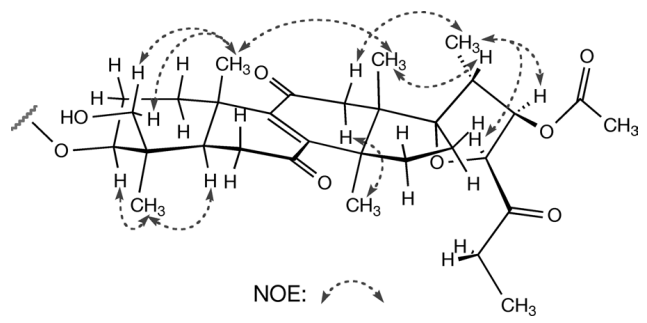

Fig. 3. Key NOE Correlations Observed in the NOESY Spectrum of $\mathbf{1}$ (in Pyridine- $d_{5}, 500 \mathrm{MHz}$ )

L-rhamnopyranosyl-( $(1 \rightarrow 2)-[O-\beta$-D-glucopyranosyl- $(1 \rightarrow 3)]$ $O$ - $\beta$-D-glucopyranosyl- $(1 \rightarrow 2)-O-\alpha$-L-arabinopyranosyl$(1 \rightarrow 6)-\beta$-D-glucopyranoside.

Compound $\mathbf{2}$, tentatively named scillanostaside $\mathrm{B}$, was obtained as an amorphous powder. The molecular formula of $\mathbf{2}$ was determined to be $\mathrm{C}_{60} \mathrm{H}_{94} \mathrm{O}_{30}$ by HR-positive-ion FABMS. The ${ }^{1} \mathrm{H}-\mathrm{NMR}$ spectrum of $\mathbf{2}$ was similar to that of $\mathbf{1}$, especially the signals due to the sugar moiety were almost superimposable. Furthermore, the ${ }^{13} \mathrm{C}-\mathrm{NMR}$ spectrum of $\mathbf{2}$ was also quite similar to that of $\mathbf{1}$, except for the loss of signal due to one carbonyl carbon and the appearance of an additional signal due to one methylene carbon. As in the case of 1, these ${ }^{1} \mathrm{H}$ - and ${ }^{13} \mathrm{C}-\mathrm{NMR}$ signals were examined in detail, and the structure of $\mathbf{2}$ was deduced to be a deoxy-derivative at C-11 of 1 (Fig. 2). This assumption was confirmed by the observation of NOE correlations similar to those of $\mathbf{1}$ in the 
Table 4. ${ }^{13} \mathrm{C}-\mathrm{NMR}$ Spectral Data for Sugar Moiety of $\mathbf{1}-\mathbf{6}$ (in Pyridine$\left.d_{5}, 125 \mathrm{MHz}\right)$

\begin{tabular}{|c|c|c|c|c|c|c|}
\hline & 1 & 2 & 3 & 4 & 5 & 6 \\
\hline Glc-1 & 106.2 & 106.1 & 105.9 & 106.1 & 106.0 & 106.0 \\
\hline 2 & 75.2 & 75.3 & 75.2 & 75.3 & 75.3 & 75.3 \\
\hline 3 & 78.1 & 78.2 & 78.1 & 78.2 & 78.2 & 78.2 \\
\hline 4 & 72.6 & 72.4 & 72.4 & 72.5 & 72.5 & 72.5 \\
\hline 5 & 75.4 & 75.8 & 75.5 & 75.5 & 75.5 & 75.5 \\
\hline 6 & 68.7 & 68.6 & 68.5 & 68.6 & 68.6 & 68.5 \\
\hline Ara-1 & 101.1 & 101.2 & 101.1 & 101.2 & 101.2 & 101.1 \\
\hline 2 & 77.6 & 77.6 & 77.5 & 77.5 & 77.5 & 77.6 \\
\hline 3 & 71.6 & 71.6 & 71.6 & 71.5 & 71.6 & 71.5 \\
\hline 4 & 66.7 & 66.8 & 66.8 & 66.8 & 66.8 & 66.8 \\
\hline 5 & 62.8 & 62.8 & 62.8 & 62.8 & 62.8 & 62.8 \\
\hline Glc'-1 & 102.5 & 102.3 & 102.3 & 102.4 & 102.4 & 102.4 \\
\hline 2 & 76.9 & 76.9 & 76.9 & 76.8 & 77.0 & 76.9 \\
\hline 3 & 88.9 & 89.1 & 88.9 & 89.0 & 88.9 & 89.0 \\
\hline 4 & 69.1 & 69.2 & 69.1 & 69.0 & 69.1 & 69.1 \\
\hline 5 & 77.8 & 77.7 & 77.8 & 77.7 & 77.7 & 77.7 \\
\hline 6 & 61.8 & 61.8 & 61.7 & 61.7 & 61.7 & 61.8 \\
\hline Rha-1 & 102.0 & 102.0 & 101.8 & 101.9 & 101.9 & 101.9 \\
\hline 2 & 72.1 & 72.2 & 72.0 & 72.1 & 72.1 & 72.1 \\
\hline 3 & 72.5 & 72.5 & 72.4 & 72.5 & 72.5 & 72.5 \\
\hline 4 & 74.0 & 74.1 & 73.9 & 74.1 & 74.0 & 74.1 \\
\hline 5 & 69.7 & 69.7 & 69.6 & 69.7 & 69.7 & 69.7 \\
\hline 6 & 18.7 & 18.7 & 18.6 & 18.7 & 18.7 & 18.7 \\
\hline Glc"-1 & 104.2 & 104.3 & 103.7 & 103.8 & 103.7 & 103.7 \\
\hline 2 & 74.9 & 74.9 & 73.5 & 73.6 & 73.6 & 73.6 \\
\hline 3 & 78.3 & 78.4 & 88.1 & 88.2 & 88.2 & 88.2 \\
\hline 4 & 71.4 & 71.4 & 69.4 & 69.5 & 69.5 & 69.5 \\
\hline 5 & 78.5 & 78.6 & 77.9 & 77.9 & 77.9 & 77.9 \\
\hline 6 & 62.3 & 62.3 & 62.0 & 62.0 & 62.0 & 62.1 \\
\hline Gal-1 & & & 105.2 & 105.3 & 105.4 & 105.3 \\
\hline 2 & & & 71.6 & 71.6 & 71.7 & 71.7 \\
\hline 3 & & & 83.9 & 84.2 & 84.0 & 84.3 \\
\hline 4 & & & 69.2 & 69.5 & 69.3 & 69.5 \\
\hline 5 & & & 76.8 & 76.9 & 76.8 & 76.8 \\
\hline 6 & & & 61.9 & 62.0 & 62.0 & 62.0 \\
\hline Glc"'-1 & & & 105.6 & 106.0 & 105.7 & 106.1 \\
\hline 2 & & & 75.2 & 75.7 & 75.3 & 75.7 \\
\hline 3 & & & 77.4 & 78.3 & 77.4 & 78.3 \\
\hline 4 & & & 71.4 & 71.7 & 71.4 & 71.6 \\
\hline 5 & & & 76.6 & 78.5 & 76.7 & 78.5 \\
\hline 6 & & & 70.0 & 62.6 & 70.0 & 62.6 \\
\hline Xyl-1 & & & 105.6 & & 105.7 & \\
\hline 2 & & & 74.7 & & 74.8 & \\
\hline 3 & & & 78.1 & & 78.2 & \\
\hline 4 & & & 70.9 & & 71.0 & \\
\hline 5 & & & 66.9 & & 67.0 & \\
\hline
\end{tabular}

$\delta$ in ppm from TMS.

NOESY spectrum of $\mathbf{2}$. Consequently, the structure of $\mathbf{2}$ was found to be $(22 R, 23 S)$-22-acetoxy-17 $\alpha, 23$-epoxy-3 $\beta, 29$-dihydroxy-27-nor-lanost-8-ene-7,24-dione 3- $O$ - $\alpha$-L-rhamnopyranosyl- $(1 \rightarrow 2)$-[ $O$ - $\beta$-D-glucopyranosyl- $(1 \rightarrow 3)]-O-\beta$-D-glucopyranosyl- $(1 \rightarrow 2)-O-\alpha$-L-arabinopyranosyl- $(1 \rightarrow 6)-\beta$-Dglucopyranoside.

Compound $\mathbf{3}$, tentatively named scillanostaside $\mathrm{C}$, was obtained as an amorphous powder. In negative-ion FAB-MS, 3 gave an $[\mathrm{M}-\mathrm{H}]^{-}$ion peak at $\mathrm{m} / z 1677$ along with fragment ion peaks at $m / z 1545$ [1677-132 $\left(\mathrm{C}_{5} \mathrm{H}_{8} \mathrm{O}_{4} \text {, pentosyl unit) }\right]^{-}$, $1531[1677-146]^{-}, 1383[1545-162]^{-}, 1237$ [1383$146]^{-}, 1221[1383-162]^{-}, 1075[1221-146]^{-}, 1059$ $[1221-162]^{-}, 913[1059-146]^{-}, 751[913-162]^{-}, 619$ [751-132] $]^{-}$, and 457 [619-162] $]^{-}$(Fig. 4). HR-positive-ion FAB-MS showed the molecular formula of $\mathbf{3}$ to be $\mathrm{C}_{75} \mathrm{H}_{122} \mathrm{O}_{41}$. The ${ }^{1} \mathrm{H}-\mathrm{NMR}$ spectrum of $\mathbf{3}$, which was analo- gous to that of $\mathbf{6}$, showed signals due to four tertiary methyl groups $(\delta 1.54,1.52,0.94,0.91)$, two secondary methyl groups $[\delta 1.72(\mathrm{~d}, J=6.0 \mathrm{~Hz}), 1.04(\mathrm{~d}, J=7.0 \mathrm{~Hz})]$, one primary methyl group $[\delta 1.07(\mathrm{t}, J=7.5 \mathrm{~Hz})]$, and eight anomeric protons $[\delta 6.16$ (brs), 5.26 (brs), 5.18 (d, $J=$ $7.5 \mathrm{~Hz}), 5.16(\mathrm{~d}, J=7.5 \mathrm{~Hz}), 5.09(\mathrm{~d}, J=8.0 \mathrm{~Hz}), 4.96(\mathrm{~d}$, $J=7.5 \mathrm{~Hz}$ ), 4.93 (d, $J=7.5 \mathrm{~Hz}), 4.84$ (d, $J=7.5 \mathrm{~Hz}$ )] (Table 5). The ${ }^{13} \mathrm{C}-\mathrm{NMR}$ spectrum of $\mathbf{3}$, which was also similar to that of 6 with additional signals due to one pentosyl unit, contained signals assignable to one keto carbonyl carbon $(\delta$ $212.6)$, two olefinic carbons ( $\delta$ 135.2, 134.5), and eight anomeric carbons $(\delta$ 105.9, 105.6, 105.6, 105.2, 103.7, $102.3,101.8,101.1)$. These signals were assigned with the help of 2D-NMR techniques as in the case of $\mathbf{1}$, and the assigned data of Agl were superimposable on those of $\mathbf{6}$ (Table 3 ). Thus, 3 was determined to be an octaglycoside of 15-deoxyeucosterol. On acidic hydrolysis, 3 afforded L-rhamnose, L-arabinose, D-xylose, D-glucose, and D-galactose. Moreover, the glycosidic linkages in glucopyranosyl, galactopyranosyl, and xylopyranosyl units were $\beta$ and those in arabinopyranosyl and rhamnopyranosyl units were $\alpha$ based on the ${ }^{1} \mathrm{H}$ and ${ }^{13} \mathrm{C}$-NMR spectral data. In the HMBC spectrum of $\mathbf{3}$, key correlations were observed between $\mathrm{H}-1$ of Glc and C-3 of Agl; H-1 of Ara and C-6 of Glc; H-1 of Glc' and C-2 of Ara; H-1 of Rha and C-2 of Glc'; H-1 of Glc" and C-3 of Glc', H1 of galactosyl unit (Gal) and $\mathrm{H}-3$ of Glc"; H-1 of firth glucosyl unit (Glc"') and C-3 of Gal; H-1 of xylosyl unit (Xyl) and C-6 of Glc" (Fig. 2). These data showed that for 3, one $\beta$-Dxylopyranosyl unit may be attached to OH-6 of Glc'" of 6 . This was confirmed by the following evidence. Comparing the chemical shifts of signals due to the sugar moieties between 3 and 6, glycosylation shifts ${ }^{12,13)}$ were observed at C-5 and C-6 of Glc"' with magnitudes -1.9 and $+7.4 \mathrm{ppm}$, respectively, with the appearance of signals due to one terminal xylopyranosyl unit. The resonances of other signals were almost identical to those of $\mathbf{6}$. In addition, the HR-positive-ion FAB-MS of the peracetate (3a) of $\mathbf{3}$ revealed fragment ion peaks at $m / z 259.0812,273.0966,835.2495$, and 1123.3357, which were assigned to the fragment ions of the 2,3,4-O-triacetylxylopyranosyl unit, the 2,3,4-O-triacetylrhamnopyranosyl unit, the 2,3,4-O-triacetylxylopyranosyl-( $(1 \rightarrow 6)-O$ $(2,3,4-O$-triacetyl $)$ glucopyranosyl- $(1 \rightarrow 3)-O-(2,4,6-O$-triacetyl)galactopyranosyl unit, and the 2,3,4- $O$-triacetylxylopyranosyl-( $1 \rightarrow 6)-O-(2,3,4-O$-triacetyl $)$ glucopyranosyl$(1 \rightarrow 3)-O-(2,4,6-O$-triacetyl)galactopyranosyl- $(1 \rightarrow 3)-O$ (2,4,6-O-triacetyl)glucopyranosyl unit, respectively, whereas a fragment ion peak $\left(\left[\mathrm{C}_{14} \mathrm{H}_{19} \mathrm{O}_{9}\right]^{+}\right)$generated from a 2,3,4,6tetracaetylhexosyl unit was not detected. Thus, 3 was concluded to be 15-deoxyeucosterol 3-O- $\beta$-D-xylopyranosyl$(1 \rightarrow 6)-O$ - $\beta$-D-glucopyranosyl- $(1 \rightarrow 3)-O$ - $\beta$-D-galactopyranosyl- $(1 \rightarrow 3)-O-\beta$-D-glucopyranosyl- $(1 \rightarrow 3)-[O-\alpha$-Lrhamnopyranosyl-( $1 \rightarrow 2)]-O-\beta$-D-glucopyranosyl- $(1 \rightarrow 2)-O$ $\alpha$-L-arabinopyranosyl-( $1 \rightarrow 6)$ - $\beta$-D-glucopyranoside.

Compound 4, tentatively named scillanostaside D, was obtained as an amorphous powder, and negative-ion FAB-MS showed an $[\mathrm{M}-\mathrm{H}]^{-}$ion peak at $\mathrm{m} / z 1589$ together with fragment ion peaks at $m / z 1443[1589-146]^{-}, 1427$ [1589$162]^{-}, 1281\left[_{1427-146]^{-},} 1265[1427-162]^{-}, 1103\right.$ $[1265-162]^{-}, 957[1103-146]^{-}, 795[957-162]^{-}, 663$ $[795-132]^{-}$, and $501[663-162]^{-}$. The molecular formula of 4 was analyzed as $\mathrm{C}_{71} \mathrm{H}_{114} \mathrm{O}_{39}$ using HR-positive-ion FAB- 
Table 5. ${ }^{1} \mathrm{H}-\mathrm{NMR}$ Spectral Data for Sugar Moiety of 3-6 (in Pyridine- $d_{5}, 500 \mathrm{MHz}$ )

\begin{tabular}{|c|c|c|c|c|}
\hline & 3 & 4 & 5 & 6 \\
\hline Glc-1 & $4.93 \mathrm{~d}(7.5)$ & $4.94 \mathrm{~d}(8.0)$ & $4.94 \mathrm{~d}(8.0)$ & $4.96 \mathrm{~d}(8.0)$ \\
\hline 2 & 3.96 & 3.97 & 3.98 & 3.97 \\
\hline 3 & 4.18 & 4.16 & 4.18 & 4.16 \\
\hline 4 & 4.19 & 4.17 & 4.19 & 4.17 \\
\hline 5 & 3.97 & 4.02 & 3.99 & 4.01 \\
\hline $6 a$ & 4.52 & 4.53 & 4.53 & 4.53 \\
\hline $6 b$ & 4.27 & 4.26 & 4.26 & 4.26 \\
\hline Ara-1 & 5.26 br s & $5.28 \mathrm{~d}(2.5)$ & $5.28 \mathrm{~d}(3.0)$ & 5.30 br s \\
\hline 2 & 4.66 & 4.66 & 4.66 & 4.66 \\
\hline 3 & 4.66 & 4.65 & 4.66 & 4.66 \\
\hline 4 & 4.52 & 4.52 & 4.53 & 4.53 \\
\hline $5 a$ & 4.35 & 4.35 & 4.36 & $4.36 \mathrm{dd}(5.0,11.5)$ \\
\hline $5 b$ & 3.90 & 3.89 & 3.90 & 3.90 \\
\hline Glc'-1 & $5.16 \mathrm{~d}(7.5)$ & $5.15 \mathrm{~d}(7.5)$ & $5.16 \mathrm{~d}(7.5)$ & $5.16 \mathrm{~d}(7.5)$ \\
\hline 2 & 4.17 & 4.16 & 4.17 & 4.18 \\
\hline 3 & 4.04 & 4.05 & 4.03 & 4.06 \\
\hline 4 & 4.04 & 4.05 & 4.03 & 4.06 \\
\hline 5 & 3.59 & 3.57 & 3.58 & 3.59 \\
\hline $6 a$ & 4.21 & 4.19 & 4.19 & 4.20 \\
\hline $6 b$ & 4.14 & 4.15 & 4.15 & 4.15 \\
\hline Rha-1 & 6.16 br s & 6.20 br s & 6.19 br s & 6.21 br s \\
\hline 2 & 4.81 brs & 4.81 brs & $4.81 \mathrm{~d}(2.5)$ & 4.81 br s \\
\hline 3 & $4.61 \mathrm{dd}(2.0,9.0)$ & $4.61 \mathrm{dd}(3.0,8.5)$ & $4.61 \mathrm{dd}((2.5,9.0)$ & 4.62 \\
\hline 4 & 4.25 & 4.25 & 4.26 & 4.26 dd $(9.0,9.0)$ \\
\hline 5 & 4.86 & $4.86 \mathrm{dq}(9.0,6.5)$ & $4.86 \mathrm{dq}(9.0,6.5)$ & $4.87 \mathrm{dq}(9.0,6.5)$ \\
\hline 6 & $1.72 \mathrm{~d}(6.0)$ & $1.73 \mathrm{~d}(6.5)$ & $1.73 \mathrm{~d}(6.5)$ & $1.74 \mathrm{~d}(6.5)$ \\
\hline Glc"-1 & $4.96 \mathrm{~d}(7.5)$ & $4.97 \mathrm{~d}(8.0)$ & $4.97 \mathrm{~d}(7.5)$ & $4.97 \mathrm{~d}(8.0)$ \\
\hline 2 & 3.91 & 3.91 & 3.91 & 3.92 \\
\hline 3 & 4.11 & 4.11 & 4.11 & 4.11 \\
\hline 4 & 3.90 & 3.91 & 3.90 & 3.90 \\
\hline 5 & 3.91 & 3.91 & 3.90 & 3.91 \\
\hline $6 a$ & 4.41 & 4.42 & 4.40 & $4.43 \mathrm{dd}(3.5,11.5)$ \\
\hline $6 b$ & 4.09 & 4.08 & 4.09 & $4.10 \mathrm{dd}(5.0,11.5)$ \\
\hline Gal-1 & $5.09 \mathrm{~d}(8.0)$ & $5.12 \mathrm{~d}(7.5)$ & $5.08 \mathrm{~d}(7.5)$ & $5.11 \mathrm{~d}(8.0)$ \\
\hline 2 & $4.59 \mathrm{dd}(8.0,9.0)$ & $4.61 \mathrm{dd}(7.5,8.5)$ & $4.61 \mathrm{dd}(7.5,9.0)$ & 4.63 \\
\hline 3 & 4.23 & 4.21 & 4.24 & 4.21 \\
\hline 4 & 4.75 br d (3.0) & 4.65 & 4.78 & 4.65 \\
\hline 5 & 4.02 & 4.03 & 4.01 & 4.03 \\
\hline $6 a$ & 4.37 & 4.37 & 4.37 & $4.37 \mathrm{dd}(3.5,11.0)$ \\
\hline $6 b$ & 4.21 & 4.23 & 4.21 & 4.23 \\
\hline Glc"'-1 & $5.18 \mathrm{~d}(7.5)$ & $5.31 \mathrm{~d}(7.5)$ & $5.21 \mathrm{~d}(7.5)$ & $5.31 \mathrm{~d}(8.0)$ \\
\hline 2 & 3.96 & 4.00 & 3.96 & 4.01 \\
\hline 3 & 4.16 & 4.25 & 4.17 & 4.24 \\
\hline 4 & 3.99 & 4.19 & 4.01 & 4.18 \\
\hline 5 & 3.89 & 3.96 & 3.90 & 3.97 \\
\hline $6 \mathrm{a}$ & 4.76 & $4.50 \mathrm{dd}(2.0,12.0)$ & 4.79 & $4.50 \mathrm{dd}(2.5,11.5)$ \\
\hline $6 b$ & 4.10 & $4.32 \mathrm{dd}(5.5,12.0)$ & 4.11 & $4.33 \mathrm{dd}(5.5,11.5)$ \\
\hline Xyl-1 & $4.84 \mathrm{~d}(7.5)$ & & $4.88 \mathrm{~d}(7.5)$ & \\
\hline 2 & 3.97 & & 3.99 & \\
\hline 3 & 4.09 & & 4.09 & \\
\hline 4 & 4.17 & & 4.17 & \\
\hline $5 \mathrm{a}$ & 4.27 & & $4.29 \mathrm{dd}(5.0,11.5)$ & \\
\hline $5 b$ & 3.59 & & 3.61 & \\
\hline
\end{tabular}

$\delta$ in ppm from TMS (coupling constants ( $J$ in $\mathrm{Hz}$ ) are given in parentheses)

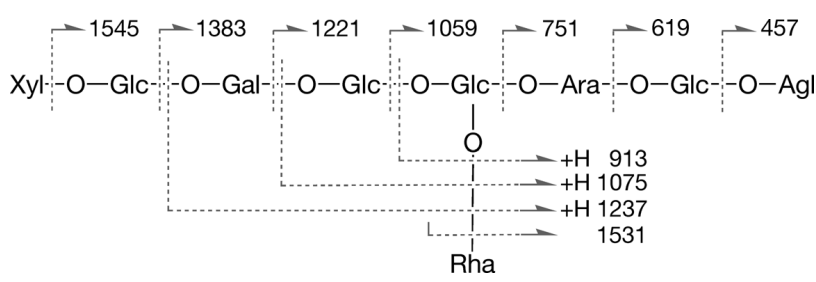

Fig. 4. Fragment Ions Observed in the Negative-Ion FAB-MS of 3
MS. The ${ }^{1} \mathrm{H}-\mathrm{NMR}$ spectrum of $\mathbf{4}$ showed signals due to four tertiary methyl groups $(\delta 1.54,1.27,0.93,0.89)$, three secondary methyl groups $[\delta 1.73(\mathrm{~d}, J=6.5 \mathrm{~Hz}), 1.50(\mathrm{~d}$, $J=7.5 \mathrm{~Hz}), 1.09(\mathrm{~d}, J=6.5 \mathrm{~Hz})]$, and seven anomeric protons [ $\delta 6.20(\mathrm{br} \mathrm{s}), 5.31(\mathrm{~d}, J=7.5 \mathrm{~Hz}), 5.28(\mathrm{~d}, J=2.5 \mathrm{~Hz}), 5.15$ (d, $J=7.5 \mathrm{~Hz}), 5.12(\mathrm{~d}, J=7.5 \mathrm{~Hz}), 4.97(\mathrm{~d}, J=8.0 \mathrm{~Hz}), 4.94$ $(\mathrm{d}, J=8.0 \mathrm{~Hz})]$. The ${ }^{13} \mathrm{C}-\mathrm{NMR}$ spectrum of $\mathbf{4}$ was analogous to that of $\mathbf{6}$; in particular, the signals due to the sugar moiety were almost superimposable, indicating signals due to one carboxyl carbon $(\delta$ 178.7), two olefinic carbons $(\delta 135.0$, $134.7)$, one acetal carbon $(\delta 117.0)$, and seven anomeric car- 
bons $(\delta 106.1,106.0,105.3,103.8,102.4,101.9,101.2)$. These NMR signals were assigned in detail with the aid of 2D-NMR techniques as done for $\mathbf{1}$. The assigned ${ }^{13} \mathrm{C}$-NMR spectral data of Agl were quite similar to those of scillasaponin D (8) (Fig. 1). ${ }^{14)}$ Consequently, the structure of 4 was concluded to be $(23 S, 24 S, 25 R)-17 \alpha, 23$-epoxy-24,29-dihydroxy-lanosta-8-en-23,26-olide 3 - $O-\beta$-D-glucopyranosyl$(1 \rightarrow 3)-O$ - $\beta$-D-galactopyranosyl-( $1 \rightarrow 3)-O$ - $\beta$-D-glucopyranosyl-( $(1 \rightarrow 3)$-[ $O-\alpha$-L-rhamnopyranosyl- $(1 \rightarrow 2)]-O-\beta$-D-glucopyranosyl-( $(1 \rightarrow 2)-O$ - $\alpha$-L-arabinopyranosyl- $(1 \rightarrow 6)-\beta$-Dglucopyranoside.

Compound $\mathbf{5}$, tentatively named scillanostaside E, was obtained as an amorphous powder, and positive-ion FAB-MS showed an $[\mathrm{M}-\mathrm{H}]^{-}$ion peak at $\mathrm{m} / \mathrm{z} 1721$, which was 132 mass units larger than that of $\mathbf{4}$, along with fragment ion peaks at $\mathrm{m} / \mathrm{z} 1589$ [1721-132] $]^{-}, 1575[1721-146]^{-}, 1427$ $[1589-162]^{-}, 1265[1427-162]^{-}, 1119[1265-146]^{-}$, $1103[1265-162]^{-}, 957[1103-146]^{-}, 795\left[^{2} 957-162\right]^{-}$, $663[795-132]^{-}$, and $501[663-162]^{-}$. The molecular formula of 5 was determined to be $\mathrm{C}_{76} \mathrm{H}_{122} \mathrm{O}_{43}$ by HR-positiveion FAB-MS. The ${ }^{1} \mathrm{H}$ - and ${ }^{13} \mathrm{C}-\mathrm{NMR}$ spectral data of the sugar moiety and $\mathrm{Agl}$ were considerably similar to those of $\mathbf{3}$ and $\mathbf{4}$, respectively. On the basis of these data, 5 was determined to be $(23 S, 24 S, 25 R)$-17 $\alpha, 23$-epoxy-24,29-dihydroxylanosta-8-en-23,26-olide 3 - $O$ - $\beta$-D-xylopyranosyl- $(1 \rightarrow 6)-O$ $\beta$-D-glucopyranosyl-( $1 \rightarrow 3)-O$ - $\beta$-D-galactopyranosyl-( $1 \rightarrow 3)$ $O$ - $\beta$-D-glucopyranosyl-( $1 \rightarrow 3)$-[O- $\alpha$-L-rhamnopyranosyl$(1 \rightarrow 2)]-O-\beta$-D-glucopyranosyl- $(1 \rightarrow 2)-O$ - $\alpha$-L-arabinopyranosyl-( $1 \rightarrow 6)-\beta$-D-glucopyranoside.

The study of the bulbs of $S$. scilloides resulted in the isolation and structural elucidation of three new norlanostanetype triterpene glycosides, named scillanostasides A, B, and $\mathrm{C}$, and two new lanostane-type triterpene glycosides, scillanostasides D and E, along with one known norlanostanetype triterpene glycoside. Among them, each scillanostasides $\mathrm{A}$ and $\mathrm{B}$ had new aglycones; furthermore, the sugar moiety attached to C-3 of the aglycones of scillanostasides $\mathrm{C}$ and $\mathrm{E}$ was a new octasaccharide.

\section{Experimental}

All instruments and materials used were the same as cited in a previous report ${ }^{15)}$ unless otherwise specified.

Plant Material The bulbs of $S$. scilloides were cultivated in Kumamoto prefecture, Japan, and were harvested in August 2005, and identified by one of authors (T. Nohara). A voucher specimen has been deposited at the laboratory of Natural Products Chemistry, School of Agriculture, Tokai University.

Extraction and Isolation The crushed fresh bulbs of S. scilloides $(18.5 \mathrm{~kg})$ were extracted with $\mathrm{MeOH}$ at room temperature, and the solvent was removed under reduced pressure to give a syrup $(3521.7 \mathrm{~g})$. The $\mathrm{MeOH}$ extract was suspended in $\mathrm{H}_{2} \mathrm{O}$ and successively extracted with EtOAc and $\mathrm{BuOH}$. The aqueous layer was chromatographed over Diaion HP20 column $\left(\mathrm{H}_{2} \mathrm{O}, \mathrm{MeOH}\right.$, acetone) to afford $\mathrm{MeOH}$ eluate fraction (fr.) and acetone eluate fr. The $\mathrm{MeOH}$ eluate fr. $(76.7 \mathrm{~g})$ was further subjected to Diaion HP20 column $\left(\mathrm{H}_{2} \mathrm{O}, 50 \% \mathrm{MeOH}, 60 \% \mathrm{MeOH}, 70 \% \mathrm{MeOH}, 80 \% \mathrm{MeOH}, 90 \%\right.$ $\mathrm{MeOH}, \mathrm{MeOH})$ to give fractions (frs.) $1-4$. Fr. 2 (31.4 g) was chromatographed over silica gel $\left[\mathrm{CHCl}_{3}-\mathrm{MeOH}-\mathrm{H}_{2} \mathrm{O}(8: 2: 0.2,7: 3: 0.5\right.$, $6: 4: 1,0: 1: 0)]$ to give frs. $2.1-2.6$. Fr. $2.3(7.69 \mathrm{~g})$ was subjected to Chromatorex ODS (60\% MeOH, 70\% MeOH, $80 \% \mathrm{MeOH}, 90 \% \mathrm{MeOH}, \mathrm{MeOH})$ to afford frs. 2.3.1-2.3.6. HPLC (Nacalai Tesque, Inc., Kyoto, Japan, Cosmosil 5C18 AR-II, $20 \mathrm{~mm}$ i.d. $\times 250 \mathrm{~mm}, 60 \% \mathrm{MeOH})$ of fr. $2.3 .4(2.63 \mathrm{~g})$ afforded $1(42 \mathrm{mg}), 2(100 \mathrm{mg})$, and frs. 2.3.4.1-2.3.4.4. A part $(10.0 \mathrm{~g})$ of fr. $2.4(13.6 \mathrm{~g})$ was subjected to Chromatorex ODS $(70 \% \mathrm{MeOH}, 80 \%$ $\mathrm{MeOH}, 90 \% \mathrm{MeOH}, \mathrm{MeOH})$ to afford $6(8.60 \mathrm{~g})$ and frs. 2.4.1-2.4.5. Fr. $2.5(1.68 \mathrm{~g})$ was subjected to HPLC (Cosmosil 5C18 AR-II, $80 \% \mathrm{MeOH}$ ) to give frs. 2.5.1-2.5.4. Fr. 2.5.2 $(281 \mathrm{mg})$ and fr. $2.5 .4(334 \mathrm{mg})$ were each subjected to HPLC [Nacalai Tesque, Inc., Kyoto, Japan, Cosmosil 5SL-II, $20 \mathrm{~mm}$ i.d. $\left.\times 250 \mathrm{~mm}, \mathrm{CHCl}_{3}-\mathrm{MeOH}-\mathrm{H}_{2} \mathrm{O}(7: 3: 0.5,6: 4: 1)\right]$ to give 5 $(78 \mathrm{mg})$ and frs. 2.5.2.1-2.5.2.3 from fr. 2.5.2, and $\mathbf{3}(77 \mathrm{mg})$ from fr. 2.5.4. HPLC (Cosmosil 5C18 AR-II, 70\% MeOH) of fr. 2.5.2.2 (85 mg) afforded 4 (27 mg).

1: Amorphous powder. $[\alpha]_{\mathrm{D}}^{25}-33.2^{\circ}\left(c=4.4\right.$, pyridine). UV $\lambda_{\max }(\mathrm{MeOH})$ $\mathrm{nm}(\log \varepsilon): 264$ (3.65). Positive-ion FAB-MS m/z: $1331[\mathrm{M}+\mathrm{Na}]^{+}$. HR-positive-ion FAB-MS m/z: 1331.5508 (Calcd for $\mathrm{C}_{60} \mathrm{H}_{92} \mathrm{O}_{31} \mathrm{Na}$ : 1331.5520). Negative-ion FAB-MS m/z: $1307[\mathrm{M}-\mathrm{H}]^{-}, 1247$ [1307-60] $^{-}, 1161$ $[1307-146]^{-}, \quad 1146,1101[1247-146]^{-}, 1085[1247-162]^{-}, 939$ $[1085-146]^{-}, 777[939-146]^{-}, 661,529,367 .{ }^{1} \mathrm{H}-\mathrm{NMR}$ spectral data (in pyridine- $\left.d_{5}, 500 \mathrm{MHz}\right) \delta$ : see Tables 1 and $2 .{ }^{13} \mathrm{C}-\mathrm{NMR}$ spectral data: see Tables 3 and 4.

2: Amorphous powder. $[\alpha]_{\mathrm{D}}^{25}-33.3^{\circ}\left(c=3.0\right.$, pyridine). UV $\lambda_{\max }(\mathrm{MeOH})$ $\mathrm{nm}(\log \varepsilon): 254$ (3.78). Positive-ion FAB-MS $m / z: 1317[\mathrm{M}+\mathrm{Na}]^{+}$. HR-positive-ion FAB-MS $m / z$ : 1317.5726 (Calcd for $\mathrm{C}_{60} \mathrm{H}_{94} \mathrm{O}_{30} \mathrm{Na}$ : 1317.5725). Negative-ion FAB-MS m/z: $1233[\mathrm{M}-\mathrm{H}-60]^{-}, 1087[1233-146]^{-}, 1071$ $[1233-162]^{-}, 925[1071-146]^{-}, 763[925-162]^{-}, 661[763-132]^{-} .{ }^{1} \mathrm{H}-$ NMR spectral data (in pyridine- $\left.d_{5}, 500 \mathrm{MHz}\right) \delta$ : see Tables 1 and $2 .{ }^{13} \mathrm{C}$ NMR spectral data: see Tables 3 and 4.

3: Amorphous powder. $[\alpha]_{\mathrm{D}}^{31}-77.0^{\circ}(c=1.1$, pyridine $)$. Positive-ion FABMS $m / z: 1701[\mathrm{M}+\mathrm{Na}]^{+}$. HR-positive-ion FAB-MS $m / z$ : 1701.7365 (Calcd for $\mathrm{C}_{75} \mathrm{H}_{122} \mathrm{O}_{41} \mathrm{Na}$ : 1701.7360). Negative-ion FAB-MS $m / z$ : $1677[\mathrm{M}-\mathrm{H}]^{-}$, $1545[1677-132]^{-}, 1531[1677-146]^{-}, 1383[1545-162]^{-}, 1237[1383-$ $146]^{-}, 1221[1383-162]^{-}, 1075[1221-146]^{-}, 1059[1221-162]^{-}, 913$ $[1059-146]^{-}, 751\left[^{2} 913-162\right]^{-}, 619[751-132]^{-}, 457[619-162]^{-} .{ }^{1} \mathrm{H}-$ NMR spectral data (in pyridine- $\left.d_{5}, 500 \mathrm{MHz}\right) \delta: 2.58\left(2 \mathrm{H}, \mathrm{m}, \mathrm{H}_{2}-25\right.$ of Agl), $1.54\left(3 \mathrm{H}, \mathrm{s}, \mathrm{H}_{3}-28\right.$ of $\left.\mathrm{Agl}\right), 1.52\left(3 \mathrm{H}, \mathrm{s}, \mathrm{H}_{3}-30\right.$ of $\left.\mathrm{Agl}\right), 1.07(3 \mathrm{H}, \mathrm{t}$, $J=7.5 \mathrm{~Hz}, \mathrm{H}_{3}-26$ of $\left.\mathrm{Agl}\right), 1.04\left(3 \mathrm{H}, \mathrm{d}, J=7.0 \mathrm{~Hz}, \mathrm{H}_{3}-21\right), 0.94\left(3 \mathrm{H}, \mathrm{s}, \mathrm{H}_{3}-19\right.$ of $\mathrm{Agl}), 0.91$ ( $3 \mathrm{H}, \mathrm{s}, \mathrm{H}_{3}-18$ of $\left.\mathrm{Agl}\right)$; sugar moiety: see Table $5 .{ }^{13} \mathrm{C}-\mathrm{NMR}$ spectral data: see Tables 3 and 4 .

4: Amorphous powder. $[\alpha]_{\mathrm{D}}^{31}-67.3^{\circ}(c=1.1$, pyridine). Positive-ion FABMS $m / z: 1613[\mathrm{M}+\mathrm{Na}]^{+}$. HR-positive-ion FAB-MS m/z: 1613.6830 (Calcd for $\mathrm{C}_{71} \mathrm{H}_{114} \mathrm{O}_{39} \mathrm{Na}$ : 1613.6835). Negative-ion FAB-MS m/z: $1589[\mathrm{M}-\mathrm{H}]^{-}$, $1443[1589-146]^{-}, 1427[1589-162]^{-}, 1281[1427-146]^{-}, 1265[1427-$ $162]^{-}, 1119[1265-146]^{-}, 1103[1265-162]^{-}, 957[1103-146]^{-}, 795$ $[957-162]^{-}, 663[795-132]^{-}, 501[663-162]^{-} .{ }^{1} \mathrm{H}-\mathrm{NMR}$ spectral data (in pyridine- $\left.d_{5}, 500 \mathrm{MHz}\right) \delta: 4.42(1 \mathrm{H}, \mathrm{d}, J=11.0 \mathrm{~Hz}, \mathrm{Ha}-29$ of Agl $), 3.65(1 \mathrm{H}$, d, $J=11.0 \mathrm{~Hz}, \mathrm{Hb}-29$ of Agl), $3.31(1 \mathrm{H}, \mathrm{dq}, J=4.5,7.5 \mathrm{~Hz}, \mathrm{H}-25$ of Agl), $2.70(1 \mathrm{H}, \mathrm{d}, J=14.5 \mathrm{~Hz}, \mathrm{Ha}-22 \mathrm{fog}), 2.52(1 \mathrm{H}, \mathrm{dd}, J=6.5,14.5 \mathrm{~Hz}, \mathrm{Hb}-22$ of Agl), $2.20\left(1 \mathrm{H}\right.$, dq-like, $J=6.5,6.5 \mathrm{~Hz}, \mathrm{H}-20$ of Agl), $1.54\left(3 \mathrm{H}, \mathrm{s}, \mathrm{H}_{3}-28\right.$ of $\mathrm{Agl}), 1.50\left(3 \mathrm{H}, \mathrm{d}, J=7.5 \mathrm{~Hz}, \mathrm{H}_{3}-27\right.$ of $\left.\mathrm{Agl}\right), 1.27$ ( $3 \mathrm{H}, \mathrm{s}, \mathrm{H}_{3}-30$ of Agl), $1.09\left(3 \mathrm{H}, \mathrm{d}, J=6.5 \mathrm{~Hz}, \mathrm{H}_{3}-21\right), 0.93\left(3 \mathrm{H}, \mathrm{s}, \mathrm{H}_{3}-19\right.$ of $\left.\mathrm{Agl}\right), 0.89\left(3 \mathrm{H}, \mathrm{s}, \mathrm{H}_{3}-\right.$ 18 of Agl); sugar moiety: see Table $5 .{ }^{13} \mathrm{C}-\mathrm{NMR}$ spectral data: see Tables 3 and 4 .

5: Amorphous powder. $[\alpha]_{\mathrm{D}}^{31}-56.0^{\circ}(c=1.1$, pyridine). Positive-ion FABMS $m / z$ : $1745[\mathrm{M}+\mathrm{Na}]^{+}$. HR-positive-ion FAB-MS m/z: 1745.7228 (Calcd for $\mathrm{C}_{76} \mathrm{H}_{122} \mathrm{O}_{43} \mathrm{Na}$ : 1745.7258). Negative-ion FAB-MS m/z: $1721[\mathrm{M}-\mathrm{H}]^{-}$, $1589[1721-132]^{-}, 1575[1721-146]^{-}, 1427[1589-162]^{-}, 1265$ $[1427-162]^{-}, 1119[1265-146]^{-}, 1103[1265-162]^{-}, 957[1103-146]^{-}$, $795[957-162]^{-}, 663[795-132]^{-}, 501[663-162]^{-}$. ${ }^{1} \mathrm{H}-\mathrm{NMR}$ spectral data (in pyridine- $\left.d_{5}, 500 \mathrm{MHz}\right) \delta: 4.42(1 \mathrm{H}, \mathrm{d}, J=11.0 \mathrm{~Hz}, \mathrm{Ha}-29$ of Agl), $3.65(1 \mathrm{H}, \mathrm{d}, J=11.0 \mathrm{~Hz}, \mathrm{Hb}-29$ of Agl), $3.30(1 \mathrm{H}, \mathrm{dq}, J=4.5,7.0 \mathrm{~Hz}, \mathrm{H}-25$ of $\mathrm{Agl}), 2.70(1 \mathrm{H}, \mathrm{d}, J=14.5 \mathrm{~Hz}, \mathrm{Ha}-22$ of $\mathrm{Agl}), 2.52(1 \mathrm{H}, \mathrm{dd}, J=7.0$, $14.5 \mathrm{~Hz}, \mathrm{Hb}-22$ of Agl), $2.20(1 \mathrm{H}$, dq-like, $J=7.0,7.0 \mathrm{~Hz}, \mathrm{H}-20$ of Agl), $1.54\left(3 \mathrm{H}, \mathrm{s}, \mathrm{H}_{3}-28\right.$ of Agl), $1.50\left(3 \mathrm{H}, \mathrm{d}, J=7.0 \mathrm{~Hz}, \mathrm{H}_{3}-27\right.$ of $\left.\mathrm{Agl}\right), 1.27(3 \mathrm{H}$, s, $\mathrm{H}_{3}-30$ of $\left.\mathrm{Agl}\right), 1.09\left(3 \mathrm{H}, \mathrm{d}, J=7.0 \mathrm{~Hz}, \mathrm{H}_{3}-21\right), 0.93\left(3 \mathrm{H}, \mathrm{s}, \mathrm{H}_{3}-19\right.$ of $\left.\mathrm{Agl}\right)$, $0.89\left(3 \mathrm{H}, \mathrm{s}, \mathrm{H}_{3}-18\right.$ of $\left.\mathrm{Agl}\right)$; sugar moiety: see Table $5 .{ }^{13} \mathrm{C}$-NMR spectral data: see Tables 1 and 2.

6: Amorphous powder. $[\alpha]_{\mathrm{D}}^{16}-41.0^{\circ}(c=1.8$, pyridine). Positive-ion FABMS $m / z: 1569[\mathrm{M}+\mathrm{Na}]^{+} .{ }^{1} \mathrm{H}-\mathrm{NMR}$ spectral data (in pyridine- $d_{5}, 500 \mathrm{MHz}$ ) $\delta: 2.57\left(2 \mathrm{H}, \mathrm{m}, \mathrm{H}_{2}-25\right.$ of $\left.\mathrm{Agl}\right), 1.55\left(3 \mathrm{H}, \mathrm{s}, \mathrm{H}_{3}-28\right.$ of $\left.\mathrm{Agl}\right), 1.53\left(3 \mathrm{H}, \mathrm{s}, \mathrm{H}_{3}-\right.$ 30 of Agl), 1.07 ( $3 \mathrm{H}, \mathrm{t}, J=7.5 \mathrm{~Hz}, \mathrm{H}_{3}-26$ of Agl), $1.04\left(3 \mathrm{H}, \mathrm{d}, J=6.5 \mathrm{~Hz}, \mathrm{H}_{3}-\right.$ 21), 0.94 (3H, s, $\mathrm{H}_{3}-19$ of $\left.\mathrm{Agl}\right), 0.91\left(3 \mathrm{H}, \mathrm{s}, \mathrm{H}_{3}-18\right.$ of $\left.\mathrm{Agl}\right)$; sugar moiety: see Table 5. ${ }^{13} \mathrm{C}$-NMR spectral data: see Tables 3 and 4 .

Acetylation of 3 Compound $3(10 \mathrm{mg})$ in $\mathrm{Ac}_{2} \mathrm{O}$-pyridine $(1: 1,1 \mathrm{ml})$ was left to stand at room temperature overnight. After removal of the reagent under a stream of $\mathrm{N}_{2}$, the residue was partitioned between ether $(1 \mathrm{ml} \times 3)$ and $\mathrm{H}_{2} \mathrm{O}(1 \mathrm{ml})$. The ether layer was concentrated to afford $\mathbf{3 a}(8 \mathrm{mg})$.

3a: Amorphous powder. ${ }^{1} \mathrm{H}-\mathrm{NMR}$ spectral data $\delta: 2.40(3 \mathrm{H}, \mathrm{s}), 2.38(3 \mathrm{H}$, s), $2.32(3 \mathrm{H}, \mathrm{s}), 2.28(3 \mathrm{H}, \mathrm{s}), 2.22(3 \mathrm{H}, \mathrm{s}), 2.21(3 \mathrm{H}, \mathrm{s}), 2.20(6 \mathrm{H}, \mathrm{s}), 2.17$ $(3 \mathrm{H}, \mathrm{s}), 2.13(3 \mathrm{H}, \mathrm{s}), 2.12(6 \mathrm{H}, \mathrm{s}), 2.11(6 \mathrm{H}, \mathrm{s}), 2.10(6 \mathrm{H}, \mathrm{s}), 2.08(3 \mathrm{H}, \mathrm{s})$, $2.05(3 \mathrm{H}, \mathrm{s}), 1.99(3 \mathrm{H}, \mathrm{s}), 1.98(3 \mathrm{H}, \mathrm{s}), 1.98(3 \mathrm{H}, \mathrm{s}), 1.96(3 \mathrm{H}, \mathrm{s}), 1.92(3 \mathrm{H}$, s). HR-positive-ion FAB-MS m/z: 1123.3357 (Calcd for $\mathrm{C}_{47} \mathrm{H}_{63} \mathrm{O}_{31}$ : 
1123.3353), 835.2495 (Calcd for $\mathrm{C}_{35} \mathrm{H}_{47} \mathrm{O}_{23}: 835.2509$ ), 273.0966 (Calcd for $\mathrm{C}_{12} \mathrm{H}_{17} \mathrm{O}_{7}: 273.0974$ ), 259.0812 (Calcd for $\mathrm{C}_{11} \mathrm{H}_{15} \mathrm{O}_{7}:$ 259.0818).

Sugar Analysis Compounds $1(5 \mathrm{mg})$ and $3(15 \mathrm{mg})$ were each heated in $2 \mathrm{M} \mathrm{HCl}(\mathbf{1}, 1 \mathrm{ml} ; \mathbf{3}, 3 \mathrm{ml})$ at a temperature of $95^{\circ} \mathrm{C}$ for $1 \mathrm{~h}$. The reaction mixture was extracted with AcOEt. The aqueous layer was neutralized with Amberlite MB-3 (Organo Co.) and then evaporated under reduced pressure to give a monosaccharide fr. This fr. was analyzed by HPLC under the following conditions: column, Shodex RS-Pac DC-613, Showa Denko, $150 \mathrm{~mm} \times 6.0 \mathrm{~mm}$; solvent, $\mathrm{CH}_{3} \mathrm{CN}-\mathrm{H}_{2} \mathrm{O}(3: 1)$; flow rate, $1.0 \mathrm{ml} / \mathrm{min}$; column temperature, $70^{\circ} \mathrm{C}$; detector, JASCO OR-2090 plus; pump, JASCO PU-2080; and column oven, JASCO CO-2060. The retention time $\left(t_{\mathrm{R}}\right)$ and optical activity of each of the monosaccharides were detected as follows. LRhamnose $\left[t_{\mathrm{R}}, 3.7 \mathrm{~min}\right.$; optical activity, negative $]$, L-arabinose $\left[t_{\mathrm{R}}, 5.7 \mathrm{~min}\right.$; optical activity, positive], and D-glucose $\left[t_{\mathrm{R}}, 6.8 \mathrm{~min}\right.$; optical activity, positive] for 1; L-rhamnose [ $t_{\mathrm{R}}, 3.6 \mathrm{~min}$; optical activity, negative], D-xylose [ $t_{\mathrm{R}}$, $5.1 \mathrm{~min}$; optical activity, positive], $\mathrm{L}$-arabinose $\left[t_{\mathrm{R}}, 5.7 \mathrm{~min}\right.$; optical activity, positive], D-glucose [ $t_{\mathrm{R}}, 6.8 \mathrm{~min}$; optical activity, positive], and D-galactose $\left[t_{\mathrm{R}}, 7.2 \mathrm{~min}\right.$; optical activity, positive] for $\mathbf{3}$. However, the ethyl acetate extract exhibited several spots by TLC, and the aglycones of $\mathbf{1}$ and $\mathbf{3}$ could not be obtained.

Acknowledgment We express our appreciation to Mr. H. Harazono of Fukuoka University for his measurement of the FAB-MS.

\section{References}

1) “Chuyaku Daijiten,” ed. by Koso Shin Igakuin, Shanghai Kagaku Gijutsu Shuppansha, 1978, p. 2270.

2) Kouno I., Komori T., Kawasaki T., Tetrahedron Lett., 46, 4569-4572
(1973).

3) Kouno I., Noda N., Ida I., Sholichin M., Miyahara K., Komori T., Kawasaki T., Liebigs Ann. Chem., 1982, 306-314 (1982).

4) Sholichin M., Miyahara K., Kawasaki T., Heterocycles, 17, 251-257 (1982).

5) Sholichin M., Miyahara K., Kawasaki T., Chem. Pharm. Bull., 33, 1756-1759 (1985)

6) Lee S.-M., Chun H.-K., Lee C.-H., Min B.-S., Lee E.-S., Kho Y.-H., Chem. Pharm. Bull., 50, 1245-1249 (2002).

7) Nishida Y., Eto M., Miyashita H., Ikeda T., Yamaguchi K., Yoshimitsu H., Nohara T., Ono M., Chem. Pharm. Bull., 56, 1022-1025 (2008).

8) Seo S., Tomita Y., Tori K., Yoshimura Y., J. Am. Chem. Soc., 100, 3331-3339 (1978)

9) Mizutani K., Hayashi A., Kasai R., Tanaka O., Yoshida N., Nakajima T., Carbohydr. Res., 126, 177-189 (1984).

10) Mimaki Y., Ori K., Kubo S., Sashida Y., Nikaido T., Song L.-G., Ohmoto T., Chem. Lett., 1992, 1863-1866 (1992).

11) Amchler G., Frahm A. W., Müller-Doblies D., Müller-Doblies U., Phytochemistry, 47, 429-436 (1998).

12) Kasai R., Suzuo M., Asakawa J., Tanaka O., Tetrahedron Lett., 1977, 175-178 (1977).

13) Tori K., Seo S., Yoshimura Y., Arita H., Tomita Y., Tetrahedron Lett., 1977, 179-182 (1977).

14) Mimaki Y., Kubo S., Kinoshita Y., Sashida Y., Song L.-G., Nikaido T., Ohmoto T., Phytochemistry, 34, 791 -797 (1993).

15) Ono M., Mishima K., Yamasaki T., Masuoka C., Okawa M., Kinjo J., Ikeda T., Nohara T., J. Nat. Med., 63, 86-90 (2009). 